\title{
OCCURRENCE OF ANTIBODIES TO TEICHOIC ACID IN PATIENTS WITH DISEASES OTHER THAN STAPHYLOCOCCAL INFECTION
}

\author{
Ulla larinkari, Marjatta Leirisalo*, P. J. Pentikäinen $\dagger$, Ulla Turunen*, \\ P. PIKKARAINEN*, M. VuORISTO*, J. Lumio $\ddagger$, TARJA RÄSÄNEN AND V. V. VALTONEN
Department of Bacteriology and Immunology, University of Helsinki, *Second and $\dagger$ Third Departments of Medicine, University Central Hospital and $\ddagger$ Aurora Municipal Hospital, Helsinki, Finland

\begin{abstract}
Summary. To determine the usefulness of the teichoic acid antibody (TAA) test in conditions where unspecific viral and bacterial antibodies are often encountered, we measured TAA by the gel-diffusion method in 475 patients without known staphylococcal disease; they included 213 patients with arthritis, 108 with liver diseases, 100 with gastro-intestinal disorders and 54 with acute pharyngitis. Positive controls were 104 patients with Staphylococcus aureus bacteraemia and 203 healthy adults were negative controls. Thirteen $(6 \%)$ of the healthy adults had positive TAA titres $(\geqslant 4)$, and the highest titre was 8 in two people $(1 \%)$. Positive titres were found in $38 \%$ of patients with $S$. aureus bacteraemia and high titres $(\geqslant 8)$ were seen in $24 \%$. Among the patients with arthritis, positive TAA titres were found significantly more often than in healthy controls in patients with Yersinia arthritis $(p<0.01)$ and systemic lupus erythematosus (SLE; $p<0.02$ ). In other patient groups, the percentage of positive TAA titres did not differ significantly from that in healthy adults. Eight $(2 \%)$ of the 475 patients without known staphylococcal infection had TAA titres $\geqslant 8$ but these high titres were not associated with any particular disease group. Only two of these eight patients had slightly raised antibody to staphylococcal $\alpha$-haemolysin. We conclude that the TAA test cannot be used as a reliable indicator of septic staphylococcal disease in patients with Yersinia arthritis or SLE, but that in general, TAA titres $\geqslant 8$ point strongly to $S$. aureus infection even in patients with autoimmune or liver diseases.
\end{abstract}

\section{INTRODUCTION}

The teichoic acid antibody (TAA) test has proved valuable in the diagnosis of bacteraemic infections caused by Staphylococcus aureus (Larinkari et al., 1977; Tuazon et al., 1978; Wheat, Kohler and White, 1978; Bayer et al., 1980; Tenenbaum and Archer, 1980). Especially high TAA titres have been found in staphylococcal endocarditis and in other complicated staphylococcal infections with metastatic abscess formation (Crowder and White, 1972; Nagel et al., 1975; Tuazon and 
Sheagren, 1976; Tuazon et al., 1978; Wheat et al., 1978; Bayer et al., 1980; Tenenbaum and Archer, 1980). Patients with atopic dermatitis often have high TAA titres without evidence of clinical infection (Larinkari, 1982a).

Teichoic acids are the major group antigen of $S$. aureus, but they are present, as a rule, in all gram-positive bacteria either as cell wall or cell membrane components (Knox and Wicken, 1973). The wall teichoic acid of $S$. aureus is a ribitol-phosphate polymer substituted with $\alpha$ - and $\beta$-linked $\mathrm{N}$-acetylglucosamine residues which are the main antigenic determinants (Sanderson, Strominger and Nathenson, 1962; Torii, Kabat and Bezer, 1964). Cross-reactions can be expected in TAA assay, because many gram-positive and also some gram-negative bacteria have structures that are antigenically similar to those of the ribitol teichoic acids of $S$. aureus (Juergens, Sanderson and Strominger, 1963; Brundish and Baddiley, 1968; Kane and Karakawa, 1969; Aasen and Oeding, 1971; Argaman, Liu and Robbins, 1974; Gmeiner et al., 1977). In practice, however, false positive TAA test results have been fairly uncommon (Crowder and White, 1972; Larinkari et al., 1977, Leffell, Folds and Wasilauskas, 1978; Martin, Greenberg and Wallace, 1979). They have been found usually in low titres in some patients with streptococcal and diphtheroid endocarditis, (Hoppes and White, 1975; Nagel et al., 1975; Tuazon et al., 1978; Bayer et al., 1980). Relatively high TAA titres have also been reported in a small fraction of healthy controls as well as patients with non-infectious diseases (Leffell et al., 1978; Tenenbaum and Archer, 1980; Larinkari, 1982a).

High levels of unspecific bacterial and viral antibodies have been reported to occur especially in patients with systemic lupus erythematosus and in patients with different liver diseases (Vesikari and Laitinen, 1974; Triger, 1976) but the occurrence of TAA in these patients has not been studied. To further define the value of the TAA test in the diagnosis of staphylococcal infections we have determined the TAA titres in various patients, without a history of staphylococcal infection, and compared the findings with those in healthy controls and in a group of patients with $S$. aureus bacteraemia.

\section{MATERIALS AND METHODS}

\section{Controls}

Healthy controls. This group consisted of 99 healthy blood donors and 104 other healthy adults; 116 were males and 87 were females, with mean age 32 (range 16-62) years. One serum sample was examined from each person. This material was used as the control group in two earlier papers (Larinkari, 1982a and $b$ ) but it is now analysed more accurately by age.

Patients with $S$. aureus bacteraemia. This positive control group comprised 104 patients with blood-culture-proven bacteraemia caused by $S$. aureus; 61 were males and 43 were females, with mean age 47 (range 2-87) years. Included were 14 patients with either liver disease or connective tissue disease as their basic illness: four had rheumatoid arthritis (RA), three had alcoholic liver disease, three cirrhosis of unknown etiology and one each had Goodpasture's syndrome, cholangitis and chronic aggressive hepatitis; one patient had uric arthritis and gallstones. The serum samples were taken 5 days to 4 weeks after the first positive blood culture. All patients.had samples taken during the second week of their illness. Sixteen patients have been included in a previous report. (Larinkari, 1982b).

\section{Patients with nonstaphylococcal disease}

A total of 475 patients in four main disease groups-arthritis, liver disease, gastro-intestinal disease and pharyngitis-were studied. The age and sex distribution of these patients is shown 
TABLE I

Age and sex distribution of 475 patients without known staphylococcal disease

\begin{tabular}{l|rrrrr}
\hline \multicolumn{1}{c|}{ Disease group } & \multicolumn{4}{|c}{ Patients } & \multicolumn{3}{c}{ Age } & $\overbrace{\text { number tested }}$ & males & females & & range \\
\hline Arthritis & 213 & 99 & 114 & 36 & $13-75$ \\
Liver disease & 108 & 52 & 56 & 49 & $19-79$ \\
Gastro-intestinal disease & 100 & 44 & 56 & 42 & $15-82$ \\
Pharyngitis & 54 & 25 & 29 & 27 & $3-71$ \\
\hline
\end{tabular}

in Table I. The diagnosis in the patients was based on generally accepted clinical, histological, microbiological and immunological criteria. None of the patients had a culture-proven staphylococcal bacteraemia in their history. Serum samples were taken from patients with acute conditions, at weekly intervals for 3-6 weeks. Follow-up sera taken during different stages of the disease were available also from several patients with chronic diseases. Only the highest TAA titre is given from each patient.

Arthritis patients. This group included 213 patients divided into the following subgroups: reactive arthritis, 56 patients ( 28 after Chlamydia trachomatis infection, 22 after Yersinia enterocolitica infection, four after Salmonella infection and two after Shigella infection); connective tissue disease, 56 (39 with definite or classical rheumatoid arthritis, nine with systemic lupus erythematosus, and eight with other connective tissue disease); Reiter's disease, 32; rheumatic fever, seven; other known polyarthritis, five; polyarthritis of unknown aetiology, 57 patients.

Liver diseases. This group consisted of 108 patients with the following diagnoses: alcoholic liver disease, 32; primary biliary cirrhosis, 21 ; liver metastases, 13; chronic active hepatitis, five; other liver diseases, (cirrhosis of unknown aetiology, infectious hepatitis, fatty degeneration, fibrosis of liver, hepatic sarcoidosis, cholangitis, hepatomegaly, icterus) 37 .

Gastro-intestinal diseases. 100 patients with different gastro-intestinal diseases had the following diagnoses: malabsorption syndrome, 60; acute gastroenteritis, 32 (10 with Salmonella infections, two with acute appendicitis and 20 with gastroenteritis of unknown aetiology); and eight patients had ulcerative colitis.

Pharyngitis. Throat cultures were taken from 54 patients with signs and symptoms of acute pharyngitis. $\beta$-haemolytic streptococci were isolated from 35 specimens (group A, 12; group C, nine; group G, three; not group A, B, C, D or G, 11).

\section{Methods}

TAA assay. TAA was measured by the gel diffusion method described previously (Larinkari et al., 1977). Twofold dilutions of serum were tested against the antigen, a sonicate of $S$. aureus strain Copenhagen diluted 200-fold. This strain contains both $\alpha$ - and $\beta$-linked $\mathrm{N}$-acetylglucosamine, predominantly the latter (Sanderson et al., 1962). Teichoic acid precipitation lines were identified by comparison with purified teichoic acid from $S$. aureus Copenhagen as reference. Titres $\geqslant 4$ were considered to be positive results.

Assay for antibody to the $\alpha$-haemolysin of S. aureus (ASta). ASta determinations were done by inhibition by the patient's serum of haemolysis of rabbit red blood cells by $\alpha$-haemolysin using the previously described method with minor modifications (Widholm, 1951). Values (IU/ml) were measured by comparing dilutions of patients' sera with the standard serum (Behringwerke ${ }^{\circledR}$, Marburg, West Germany); this had an ASta content of $1 \mathrm{IU} / \mathrm{ml}$ that gave a $50 \%$ haemolysis end point. Values $\geqslant 2 \mathrm{IU} / \mathrm{ml}$ were considered to be positive results. ASta was measured only in patients with TAA titres $\geqslant 8$.

Statistical methods. The Chi square test with Yates's correction was used for statistical comparisons. 


\section{RESULTS}

The occurrence of positive TAA titres in healthy controls and in patients with bacteraemia caused by $S$. aureus is shown in table II. Thirteen $(6 \%)$ of the 203 healthy controls had TAA titres $\geqslant 4$. The highest titre was 8 , seen in two persons. The positive titres were evenly distributed amongst all age groups. In the positive control group of 104 patients with $S$. aureus bacteraemia, the frequency of TAA titres $\geqslant 4$ was $38 \%, 24 \%$ had titres $\geqslant 8$ and $9 \%$ had titres $\geqslant 16$. The highest titre, 32 , was seen in one patient. High TAA titres were especially common in patients with $S$. aureus bacteraemia and liver disease or connective tissue disease as the basic illness (TAA $\geqslant 8$ in $50 \%$ and $33 \%$ respectively).

The TAA titres of 213 patients with arthritis are summarized in table III; 26

TABLE II

Occurrence of positive teichoic acid antibody titres in 203 healthy controls and in 104 patients with bacteraemia caused by $S$. aureus

\begin{tabular}{|c|c|c|c|c|}
\hline \multirow[b]{2}{*}{ Subject group } & \multirow{2}{*}{$\begin{array}{l}\text { Number of } \\
\text { subjects } \\
\text { tested }\end{array}$} & \multicolumn{3}{|c|}{$\begin{array}{l}\text { Number (percent) of } \\
\text { patients with TAA titre }\end{array}$} \\
\hline & & $\geqslant 4$ & $\geqslant 8$ & $\geqslant 16$ \\
\hline $\begin{array}{l}\text { Healthy controls } \\
\text { age group 16-25 years } \\
\qquad 26-35 \text { years } \\
36-45 \text { years } \\
46-62 \text { years } \\
\text { S. aureus bacteraemia } \\
\text { patients with liver disease } \\
\text { patients with connective } \\
\text { tissue disease }\end{array}$ & $\begin{array}{r}203 \\
40 \\
89 \\
51 \\
23 \\
104 \\
8 \\
\\
6\end{array}$ & $\begin{array}{c}13(6) \\
3(8) \\
6(7) \\
2(4) \\
2(9) \\
40(38) \\
6(75)\end{array}$ & $\begin{array}{l}2(1) \\
0 \\
1(1) \\
0 \\
1(4) \\
25(24) \\
4(50)\end{array}$ & $\begin{array}{l}0 \\
0 \\
0 \\
0 \\
0 \\
9(9) \\
2(25)\end{array}$ \\
\hline
\end{tabular}

TAA $=$ teichoic acid antibody.

TABLE III

Occurrence of positive teichoic acid antibody titres in 213 patients with arthritis

\begin{tabular}{|c|c|c|c|}
\hline \multirow[b]{2}{*}{ Diagnosis } & \multirow{2}{*}{$\begin{array}{l}\text { Number } \\
\text { of patients } \\
\text { tested }\end{array}$} & \multicolumn{2}{|c|}{$\begin{array}{c}\text { Number (percent) of } \\
\text { patients with TAA } \\
\text { titre }\end{array}$} \\
\hline & & $\geqslant 4$ & $\geqslant 8$ \\
\hline $\begin{array}{l}\text { Reactive arthritis } \\
\text { Chlamydia trachomatis infection } \\
\text { Yersinia enterocolitica infection } \\
\text { other known triggering infection } \\
\text { Connective tissue disease } \\
\text { rheumatoid arthritis } \\
\text { systemic lupus erythematosus } \\
\text { other connective tissue disease } \\
\text { Reiter's disease } \\
\text { Rheumatic fever } \\
\text { Other polyarthritis } \\
\text { Polyarthritis of unknown etiology }\end{array}$ & $\begin{array}{r}56 \\
28 \\
22 \\
6 \\
56 \\
39 \\
9 \\
8 \\
32 \\
7 \\
5 \\
57\end{array}$ & $\begin{array}{l}10(18) \\
4(14) \\
6^{*}(27) \\
0 \\
8(14) \\
5(13) \\
3+(33) \\
0 \\
3(9) \\
0 \\
0 \\
5(9)\end{array}$ & $\begin{array}{l}1(2) \\
1(4) \\
0 \\
0 \\
2(4) \\
1(3) \\
1(11) \\
0 \\
2(6) \\
0 \\
0 \\
0\end{array}$ \\
\hline
\end{tabular}

TAA $=$ teichoic acid antibody.

${ }^{*} \mathrm{p}<0.01 ; \dagger p<0.02$ compared with healthy controls. 
patients $(12 \%)$ had TAA titres $\geqslant 4$. Patients with Yersinia arthritis and SLE had TAA titres $\geqslant 4$ significantly more often than healthy controls $(p<0.01$ and $p<0.02$ respectively). Single high titres $(\geqslant 8)$ occurred also in some other disease groups: one patient with reactive arthritis after Chlamydia infection, one with rheumatoid arthritis and two patients with Reiter's disease.

Amongst the 208 patients with various gastro-intestinal and liver diseases, (table IV) TAA titres $\geqslant 4$ were most often seen in patients with ulcerative colitis $(12 \%)$ and primary biliary cirrhosis $(10 \%)$. Titres $\geqslant 8$ occurred only sporadically amongst patients with malabsorption syndrome, primary biliary cirrhosis and infective hepatitis.

The highest TAA titre in the 54 pharyngitis patients was 4 , seen in six patients (table V); all harboured $\beta$-haemolytic streptococci in the throat, and three of these strains belonged to group $A$.

TAA titres $\geqslant 8$ were found in eight patients; their clinical details are given in table VI. Only two of these patients had ASta values above normal; both were $2.5 \mathrm{IU} / \mathrm{ml}$. One patient with positive ASta and TAA tests also had atopic dermatitis and her spleen

\section{TABLE IV}

Occurrence of positive teichoic acid antibody titres in 108 patients with liver diseases and 100 patients with gastro-intestinal diseases

\begin{tabular}{l|ccc}
\hline & \multicolumn{3}{c}{$\begin{array}{c}\text { Number (percent) } \\
\text { of patients with }\end{array}$} \\
\multicolumn{1}{c|}{ Diagnosis } & $\begin{array}{c}\text { Number } \\
\text { of patients } \\
\text { tested }\end{array}$ & \multicolumn{2}{c}{ TAA titre } \\
\hline Liver diseases & 108 & $6(6)$ & $2(2)$ \\
alcoholic liver disease & 32 & $2(6)$ & 0 \\
primary biliary cirrhosis & 21 & $2(10)$ & $1(5)$ \\
liver metastases & 13 & 0 & 0 \\
chronic active hepatitis & 5 & 0 & 0 \\
other liver disease & 37 & $2(5)$ & $1(3)$ \\
Gastro-intestinal diseases & 100 & $4(4)$ & $1(1)$ \\
malabsorption syndrome & 60 & $2(3)$ & $1(2)$ \\
acute gastroenteritis & 32 & $1(3)$ & 0 \\
ulcerative colitis & 8 & $1(12)$ & 0 \\
\hline
\end{tabular}

TAA $=$ teichoic acid antibody

TABLE V

Occurrence of positive teichoic acid antibody titres in 54 patients with pharyngitis

\begin{tabular}{|c|c|c|c|}
\hline \multirow[b]{2}{*}{ Throat culture result } & \multirow{2}{*}{$\begin{array}{l}\text { Number } \\
\text { of patients } \\
\text { tested }\end{array}$} & \multicolumn{2}{|c|}{$\begin{array}{l}\text { Number } \\
\text { (percent) of } \\
\text { patients with } \\
\text { TAA titre }\end{array}$} \\
\hline & & $\geqslant 4$ & $\geqslant 8$ \\
\hline $\begin{array}{l}\text { Positive for } \beta \text {-haemolytic streptococci } \\
\text { group A } \\
\text { not group A } \\
\text { Negative for } \beta \text {-haemolytic streptococci }\end{array}$ & $\begin{array}{l}35 \\
12 \\
23 \\
19\end{array}$ & $\begin{array}{l}6(17) \\
3(25) \\
3(13) \\
0\end{array}$ & $\begin{array}{l}0 \\
0 \\
0 \\
0\end{array}$ \\
\hline
\end{tabular}

TAA $=$ teichoic acid antibody 
TABLE VI

Clinical details of eight patients with teichoic acid antibody titres $\geqslant 8$, without evidence of $S$. aureus infection

\begin{tabular}{|c|c|c|c|c|c|}
\hline Underlying disease & Age & Sex & TAA titre & $\begin{array}{l}\text { ASta* value } \\
(\mathrm{IU} / \mathrm{ml})\end{array}$ & Additional diagnosis \\
\hline $\begin{array}{l}\text { Reiter's disease } \\
\text { Reiter's disease } \\
\text { reactive arthritis due to }\end{array}$ & $\begin{array}{l}34 \\
42\end{array}$ & $\begin{array}{l}\mathbf{M} \\
\mathbf{M}\end{array}$ & $\begin{array}{l}8 \\
8\end{array}$ & $\begin{array}{c}<0.64 \\
0.9\end{array}$ & $\begin{array}{l}\text { none } \\
\text { none }\end{array}$ \\
\hline $\begin{array}{l}\text { Chlamydia trachomatis infection } \\
\text { sero-negative rheumatoid arthritis } \\
\text { systemic lupus erythematosus } \\
\text { malabsorption syndrome } \\
\text { primary biliary cirrhosis } \\
\text { acute viral hepatitis }\end{array}$ & $\begin{array}{l}26 \\
50 \\
20 \\
32 \\
31 \\
37\end{array}$ & $\begin{array}{l}M \\
F \\
F \\
F \\
F \\
F\end{array}$ & $\begin{array}{l}8 \\
8 \\
8 \\
16 \\
16 \\
8\end{array}$ & $\begin{array}{l}1.25 \\
0.64 \\
0.64 \\
2 \cdot 5 \\
0 \cdot 64 \\
2 \cdot 5\end{array}$ & $\begin{array}{l}\text { none } \\
\text { none } \\
\text { none } \\
\text { atopic dermatitis, splenectomy } \\
\text { none } \\
\text { psoriatic arthritis }\end{array}$ \\
\hline
\end{tabular}

TAA $=$ teichoic acid antibody

*ASta $=$ antibody to staphylococcal $\alpha$-haemolysin.

had been removed. The other patient had viral hepatitis and chronic arthritis, probably associated with psoriasis.

\section{Discussion}

In this study, relatively high TAA titres $(\geqslant 4)$ sometimes occurred in obviously healthy persons and in patients with different diseases but without known $S$. aureus infection. A TAA titre $\geqslant 4$ was twice as common in arthritis patients as in healthy controls. Patients with Yersinia arthritis and SLE were most likely to have positive TAA tests. This result resembles the previous findings of unspecific viral antibodies in SLE (Vesikari and Laitinen, 1974). Patients with Group A streptococcal pharyngitis quite often had positive TAA tests, but this group was too small for the findings to reach statistical significance. The distribution of TAA titres in patients with various gastro-intestinal and liver diseases was not different from that in healthy controls. High TAA titres $(\geqslant 8)$ occurred in a few healthy persons $(1 \%)$ as well as patients with non-staphylococcal diseases $(2 \%)$ and these were not concentrated in any particular patient group. These figures are very much smaller than the $24 \%$ found among patients with $S$. aureus bacteraemia.

The positive TAA findings in persons without active staphylococcal disease could be due to infection with cross-reactive bacteria. $\beta$-linked $\mathrm{N}$-acetylglucosamine is the main antigenic determinant both in the ribitol teichoic acid of $S$. aureus and group A streptococcal polysaccharide (Juergens et al., 1963), which may explain the moderately high TAA titres in patients with streptococcal pharyngitis; $\beta$-linked $\mathrm{N}$-acetylglucosamine is a prominent antigenic determinant also in Streptococcus bovis (Kane and Karakawa, 1969). Cross-reactions may be due also to ribitol phosphate compounds; the pneumococcal C substance is a ribitol teichoic acid (Brundish and Baddiley, 1968) and a minority of $S$. epidermidis strains have ribitol teichoic acids (Aasen and Oeding, 1971). Antibodies to Haemophilus influenzae type b capsular polysaccharide have been shown to cross-react with several gram-positive bacteria that contain ribitol teichoic acids in their cell walls, including $S$. aureus, Bacillus subtilis, B. pumilus and Lactobacillus plantarum, as well as a few pneumococcal and Escherichia coli serotypes that contain similar polysaccharides in their cell envelopes (Argaman et al., 1974). Most of these cross-reactions are, however, weak. Ribitol phosphate has been 
identified as one of the main constituents of lipopolysaccharide of three Proteus mirabilis strains (Gmeiner et al., 1977).

In patients without $S$. aureus infection, TAA has most often been reported in patients with endocarditis or bacteraemia caused by streptococci or pneumococci, $S$. epidermidis, diphtheroids and E. coli (Crowder and White, 1972; Hoppes and White, 1975; Nagel et al., 1975; Larinkari et al., 1977; Leffell et al., 1978; Tuazon et al., 1978; Tenenbaum and Archer, 1980).

Another possibility is that the high TAA titres in healthy persons and in patients without known $S$. aureus infection may be due to silent staphylococcal infections. This is less likely because the ASta values were normal in eight of the 10 persons with TAA titres $\geqslant 8$. On the other hand, it is known that in $S$. aureus bacteraemia positive TAA and ASta results often occur in different patients (Larinkari et al., 1977). One of the two patients with a slightly elevated ASta and a high TAA titre had atopic dermatitis, a condition in which elevated ASta values and TAA titres are likely to occur (Mustakallio, 1966; Larinkari, 1982a). The other patient had viral hepatitis, arthritis and psoriasis, conditions in which ASta and TAA usually remain in the normal range (Mustakallio, 1966; Larinkari, 1982a).

From the data presented we conclude that the TAA test cannot be used as a reliable indicator of septic staphylococcal infection in patients with Yersinia arthritis or SLE, but that, in general, a high TAA titre $(\geqslant 8)$ points strongly to significant infection caused by $S$. aureus even in patients with autoimmune diseases or liver diseases. At the lower level of positivity (TAA titre 4) the specificity of the TAA test for $S$. aureus infection is less good, as these low titres are seen in $6 \%$ of normal adults.

The technical assistance of Mrs Outi Vossi and Mrs Arja Ahokas is gratefully acknowledged. This study was supported by a grant from the Orion Corporation Research Foundation.

\section{REFERENCES}

Aasen, J. And Oeding, P. 1971. Antigenic studies on Staphylococcus epidermidis. Acta Pathologica et Microbiologica Scandinavica B. 79, 827-834.

Argaman, M., LiU, T.-Y. AND RobBins, J. B. 1974. Polyribitol-phosphate: an antigen of four gram-positive bacteria cross-reactive with the capsular polysaccharide of Haemophilus influenzae type b. Journal of Immunology, 112, 649-655.

Bayer, A. S., Tillman, D. B., ConCePCiOn, N. AND Guze, L. B. 1980. Clinical value of teichoic acid antibody titers in the diagnosis and management of the staphylococcemias. Western Journal of Medicine, 132, 294-300.

BRUndish, D. E. AND BADDILEY, J. 1968. Pneumococcal C-substance, a ribitol teichoic acid containing choline phosphate. Biochemical Journal, 110, 573-582.

Crowder, J. G. AND WhITE, A. 1972. Teichoic acid antibodies in staphylococcal and nonstaphylococcal endocarditis. Annals of Internal Medicine, 77, 87-90.

Gmeiner, J., MaYer, H., Fromme, I., Kotelko, K. AND ZYCH, K. 1977. Ribitol-containing lipopolysaccharides from Proteus mirabilis and their serological relationship. European Journal of Biochemistry, 72, 35-40.

HopPES, W. L. AND WhITE, A. 1975. Staphylococcal teichoic acid antibodies in serums of patients with diphtheroid endocarditis. Annals of Internal Medicine, 83, 431.

Juergens, W. G., Sanderson, A. R. AND Strominger, J. L. 1963. Chemical basis for an immunological specificity of a strain of Staphylococcus aureus. Journal of Experimental Medicine, 117, 925-935.

KANE, J. A. AND KARAKAWA, W. W. 1969 . Immunochemical studies on the cross-reactivity between Streptococcus bovis, strain S 19, and group A streptococcal carbohydrates. Journal of Immunology, 102, 870-876. 
KNOX, K. W. AND WiCKEN, A. J. 1973. Immunological properties of teichoic acids. Bacteriological Reviews, 37, 215-257.

Larinkari, U. M., Valtonen, M. V., SarVas, M. and Valtonen, V. V. 1977. Teichoic acid antibody test. Its use in patients with coagulase-positive staphylococcal bacteremia. Archives of Internal Medicine, 137, 1522-1525.

LARINKARI, U. 1982a. Serum antibody to staphylococcal teichoic acid and $\alpha$-haemolysin in dermatological patients. British Journal of Dermatology, 107, 53-58.

LARINKARI, U. 1982b. Assay of teichoic acid antibodies and antistaphylolysin in osteomyelitis patients. Scandinavian Journal of Infectious Diseases, 14, 123-126.

LefFell, M. S., FoldS, J. D. AND WasilausKas, B. 1978. Counterimmunoelectrophoretic detection of a high incidence of precipitin reactions in normal human sera against staphylococcal teichoic acids and protein A. Journal of Clinical Microbiology, 8, 591-597.

Martin, R. R., Greenberg, S. B. AND Wallace, R. J. 1979. Staphylococcal teichoic acid antibodies. Lancet, 1,731 .

MustaKallio, K. K. 1966. Antistaphylolysin (ASta) level of the blood in relation to barrier function of the skin. Multivariate analysis of survey data of 593 hospitalized patients with Besnier's prurigo (atopic eczema). Annales Medicinae Experimentalis et Biologiae Fenniae, 44, Suppl. 7, 1-53.

Nagel, J. G., Tuazon, C. U., Cardella, T. A. and Sheagren, J. N. 1975. Teichoic acid serologic diagnosis of staphylococcal endocarditis. Use of gel diffusion and counterimmunoelectrophoretic methods. Annals of Internal Medicine, 82, 13-17.

Sanderson, A. R., Strominger, J. L. AND Nathenson, S. G. 1962. Chemical structure of teichoic acid from Staphylococcus aureus, strain Copenhagen. Journal of Biological Chemistry, 237, 3603-3613.

Tenenbaum, M. J. AND ArCher, G. L. 1980. Prognostic value of teichoic acid antibodies in Staphylococcus aureus bacteremia: a reassessment. Southern Medical Journal, 73, 140-143, 149.

Toril, M., Kabat, E. A. AND BeZer, A. E. 1964. Separation of teichoic acid of Staphylococcus aureus into two immunologically distinct specific polysaccharides with $\alpha$ - and $\beta$ - $\mathrm{N}$-acetylglucosaminyl linkages respectively. Journal of Experimental Medicine, 120, 13-29.

TRIGER, D. R. 1976. Bacterial, viral and auto antibodies in acute and chronic liver disease. Annals of Clinical Research, 8, 174-181.

Tuazon, C. U. AND ShEAGREN, J. N. 1976. Teichoic acid antibodies in the diagnosis of serious infections with Staphylococcus aureus. Annals of Internal Medicine, 84, 543-546.

Tuazon, C. U., Sheagren, J. N., Choa, M. S., Marcus, D. and Curtin, J. A. 1978. Staphylococcus aureus bacteremia: Relationship between formation of antibodies to teichoic acid and development of metastatic abscesses. Journal of Infectious Diseases, 137, 57-62.

VesiKARI, T. AND LaItinen, O. 1974. Antibody levels to multiple viral antigens in systemic lupus erythematosus and some other connective tissue diseases. Annals of Clinical Research, 6, 202-214.

Wheat, L. J., Kohler, R. B. AND White, A. 1978. Solid-phase radioimmunoassay for immunoglobulin G Staphylococcus aureus antibody in serious staphylococcal infection. Annals of Internal Medicine, 89, 467-472.

WiDHOLм, O. 1951. Antistaphylolysin titres (ASta) in normal and pathological sera with especial reference to gynecological infections. Annales Medicinae Experimentalis et Biologiae Fenniae, 29, 150-157. 